
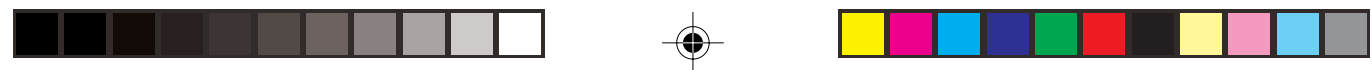

\title{
Foundation and Empire: $A$ critique of Hardt and Negri
}

\author{
Paul Thompson
}

\begin{abstract}
Hardt and Negri's Empire has become hugely influential, not only in theorising contemporary societies, but as a guide to the politics of the Left and the anti-globalisation movement. The book's sweep and ambition is indeed huge, but is not matched by the clarity of its concepts or the credibility of the evidence presented. Neither the book's analysis of regimes of global governance and the hidden abode of production, nor its articulation of a potential agency of resistance -the multitude-are convincing. In this article, Thompson complements other critiques through the use of the tools of labour process theory to critique the political economy of Empire, and to note its unfortunate similarities to conventional theories of the knowledge economy.
\end{abstract}

\footnotetext{
$\mathbf{M}$ ichael Hardt and Antonio Negri's Empire has been translated into ten languages and described as 'the most successful work of political theory to come from the left for a generation' (Bull, 200I); in La Nouvel Observateur, its authors were described as the Marx and Engels of the internet age. The book has become hugely influential, not only as a work of theory, but also as a bible of the anti-globalisation movement. It is as likely to be discussed in the salons of the fashionable literati as in the pages of the Socialist Worker Party's journal.

'Empire' is the label given to the new global order and form of sovereignty over the global political economy that has succeeded imperialism and the nation state. Its apparatus of rule is decentred and de-territorialised, yet capable of incorporating all activities within its domain, managing hybrid identities and flexible hierarchies through its own fluid networks of command. The book's sweep and ambition is huge: the analysis moves across juridical structures and practices and at least seven centuries, and through political and religious philosophy, political strategy and economic
} 


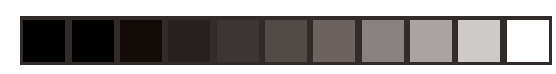

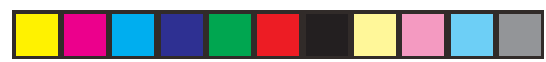

Capital $\mathcal{E}$ Class \#86

theory. Arguably, a number of its excursions-into the history of colonialism, the development of us sovereignty, and the ideas of Spinoza and Machiavelli-are marginal to the main story, which is about governance and power, capital and class.

For all its meanderings, the central project of Empire follows a relatively conventional Marxist mode of discovery: define the enemy and locate the conditions of its reproduction, then identify its gravedigger/s and the material foundations of that power. But the book does not start with the theoretical resources of Marxism. Using the poststructuralist perspectives of Michel Foucault, Giles Deleuze and Felix Guattari, Hardt and Negri set out the governance and power relations of Empire primarily through the concept of biopower. This is described as a form of power that focuses on the production and reproduction of life, and regulates social life from its interior.

However, unlike post-structuralists, Hardt and Negri are reluctant to remain at the level of discourse and, unlike postmodernists, unwilling to dispense with some notion of 'progress' and agency. Indeed, they are explicitly critical of a purely discursive approach that merely re-reads the past and is unable to grasp the real ontology of Empire, as well as being dismissive of the naive politics of postmodernism, celebrating difference in a manner that liberates the intellectual elite but leaves the dominant power untouched.

Instead, they propose a double methodology-to deconstruct hegemonic languages and structures, and thereby identify the ontological basis of a constructive alternative power residing in the actual practices of alternative agents of change (p. 47). ${ }^{1}$ Marxism, or at least their version of it, provides Empire with its theoretical sinews in this respect, though it is filtered through the discourse of informational or knowledge economies. The book moves uneasily between the identification of new agency and subjectivity in the hidden abode of production (communicative, cooperative and affective labour) and a wider agency - the multitude - that is the ultimate negation of Empire as global regime.

The aim of this paper is neither to follow every twist and turn on that path of discovery, nor to provide a detailed commentary on post-structuralism and Marxism. It is rather to examine how the central features of Empire and counterEmpire are constructed and woven into a narrative. Unfortunately, this tale is deeply flawed, notably by a neglect and misunderstanding of contemporary political economy. The 

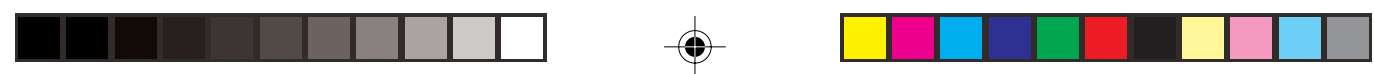

paper argues that many of these flaws are rooted in the political-theoretical current with which Negri has historically been associated.

As Steve Wright's Storming Heaven (2002) reminds us, Negri was prominent in the school of Italian Marxism ${ }^{2}$ known as 'workerism' or 'operaismo'. Using the concept of class composition, itself derived from a concrete examination of the changing conditions of labour in the workplace, operaismo identified the rise of the mass worker as the emergence of a pivotal historical figure.

An alternative picture of the new working class from the French view, with its emphasis on technicians and selfmanagement, Italian Marxism drew attention to the struggles of the deskilled or semi-skilled who refused the conditions of work and developed a new, expansive workplace politics. In doing so, it helped to create the conditions for the development of labour process theory (LPT), which has been a crucial resource for critical debates on the workplace and political economy.

A key conduit in bringing these works to the attention of a UK and international audience was the Conference of Socialist Economists (1976). Since that period, LPT, and critical workplace studies more generally, have lost some of their connections to a larger picture of production politics and political economy (see Thompson, 2003). Nevertheless, such theory and research enable a critical reading of Empire, and particularly of its unhealthy and uncritical dependence on mainstream business and management writings on the knowledge economy and knowledge work.

\section{Empire building}

The book begins with an account of the new world order, and the terminology is no mere coincidence. Empire takes the juridical categories and constituent instruments of contemporary global governance, and then gives them a very radical twist. At one level, this is no more than the standard leftist template, with the authors referring to a capitalist project to bring together economic power and political power (p. 9): a juridical formation to match the globalisation of production. The idea of the United Nations, the IMF and the World Bank as constitutional and political handmaidens to the power of global capital is hardly a new one. Yet we are 


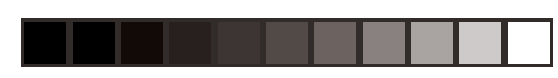

76

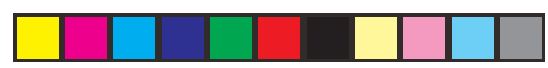

Capital $\mathcal{E}$ Class \#86

told that this world order is a complete rupture and 'nothing to do with' the old (p. 35).

What, then, constitutes this newness? The answer, we are told, is that what used to be conflict between imperialist powers has been replaced by a single power or single logic of rule (p. 9)-a totalising social process (p. Io). The capitalist world market is now one machine, with no outside to form a boundary or barrier. A second aspect to its newness operates at the level of ideology and legitimation. Empire is also a global police state, or at least one in which the new order polices the world, with the us as high sheriff, legitimating its actions in the name of human rights and justice.

Contrary to the view that postmodern power needs no master narrative, the imperial machine produces and reproduces narratives to validate and celebrate itself (p. 34). Taken together with the qualitative expansion of the boundaries of the market, such changes mean that the machine is systemic and self-validating. All power is sucked into its framework, including that which is formally a counter-power, such as the large number of nongovernmental organisations: 'It constructs social fabrics that evacuate or render ineffective any contradiction; it creates situations in which [sic], before coercively neutralizing any difference, seem to absorb it in an insignificant play of selfgenerating and self-regulating equilibria' (p. 34). Elsewhere, Hardt and Negri talk of Empire as a 'smooth place across which subjectivities glide without substantial resistance or conflict' (p. I98).

Through all this wordplay, it strikes the reader that the novelty of the analysis is primarily linguistic. Once the juridical diversions are discounted, what this studied vagueness foreshadows is a foray into full-blown poststructuralist theories of power. 'Empire' as a new form of sovereignty over the global economy draws on a Foucauldian, post-structuralist language of decentred, deterritorialised biopolitical power. In order to explain how the imperial machine is set in motion, Hardt and Negri turn to Foucault, updating his analysis of the disciplinary society.

For all the talk of capitalist production of markets, political economy is redefined as a microphysics of power'Marx re-written as Foucault', as Callinicos (200I: 40) notes $^{3}$. Language orders both commodities and subjectivities; 

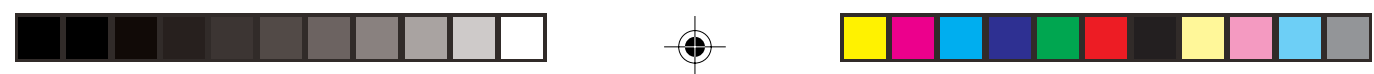

but in a nod to the material world, the role of communication industries is foregrounded (p. 33).

Suddenly, production is presented as biopolitical -an 'uninterrupted circuit of life, production and politics' ( $p$. 64). Companies, states and supra-national agencies, which previously at least had concrete half-lives, are dissolved into the ('paradoxical and contradictory') collective biopolitical body. This shadowy formulation recalls, at one level, the concept of 'social factory' that was developed by Italian autonomists in the I970s to justify their shift of attention from the workplace where, despite some successes, the Communist party still dominated, to broader community struggles. In other words, the notion that the whole of society is a factory, and is brought under the 'laws' of capitalist development, provided a Marxist gloss on a contingent political tactic.

The exposition in Empire repeats the same message, but in a more Foucauldian form: post-Fordism not only extends the factory to social life, it extends power into every social institution, from the school to the asylum. Reference to power reaching everywhere recalls Foucault's term 'capillary' although, for Hardt and Negri, he did not go far enough. As Wolfe (200I) notes, we are somehow in a post-post-Fordist regime beyond a mere disciplinary society; one in which the individual is completely consumed within the new forms of productive socialisation.

In true post-structuralist manner, this new paradigm of power is seen primarily as a shaper of subjectivities, regulating life from its interior and interiorising social integration within the subject (p. 23). Hardt and Negri extend Foucault's concept of disciplinary society into a 'society of control' in which the whole social body is conscripted and consumed within the machinery of power. ${ }^{4}$

\section{Critique: Empire as over-powered and under- specified}

In constructing Empire, Hardt and Negri want it both ways. Empire is a political subject and sovereign, imperial power. It is no mere metaphor or discourse, and is used as both noun and verb (p. 39). Yet its power is diffuse and elusive. From the beginning, despite the opening promise to analyse constitutional processes 'in some detail' (p. 3), we get very 


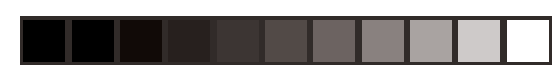

78

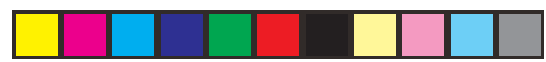

Capital $\mathcal{E}$ Class \#86

little actual description of governance mechanisms or their operation. Instead, we get an account of juridical theory and an argument about what constitutes (post-) modern forms of global power.

We thus reach a familiar point about the limits of the Foucauldian view that power is everywhere and nowhere, albeit on a different territory - that it allows the purveyor to evade and avoid any actual elaboration of how power operates. The reader has to accept metaphorical flights of fancy as a substitute for analytical description. For example, at one stage we are told that the biopolitical sphere is like a great hive in which the 'queen bee continuously oversees production and reproduction'. As to who the queen is and how she does it, we are none the wiser.

Despite reference to controlling brains and bodies, it is never entirely clear what is specifically biological about this form of power. The terms seem, again, to be used in a largely metaphorical sense. By defining the sphere of the biopolitical as 'life itself', the term is emptied of any real content. Repeated reference to the corporeal body does, however, allow the authors to indulge in some strange speculation about resistance as escape from the limits of the body itself. They encourage us to celebrate attempts to 'transform and mutate to create new posthuman bodies' (p. 215).

While we are waiting for this somewhat unlikely event, piercings and tattoos prefigure the kind of radical mutation needed to create a body that 'is completely incapable of submitting to command' (p. 216). Moving back to the general conception of Empire, what is striking is the similarity between Hardt and Negri's arguments and those of hyperglobalisers such as Omhae (I990), who speak of boundaryless worlds. Despite the different language and gloss, both reify the market and posit a new world order in which there are no intermediary institutions, no public space or politics outside the power of the market (see Omhae: I87-90).

It is difficult to mount a critique of the empirical evidence underpinning such views, given that this is decidedly thin on the ground 5 . Empire, with its emphasis on totalising powers is, nevertheless, at odds with any serious analysis of global political economy. For an analysis supposedly grounded in Marxism, there is remarkably little about the conditions of competition, other than oft-repeated phrases about world markets and globalisation. The nearest we get to 'evidence' 

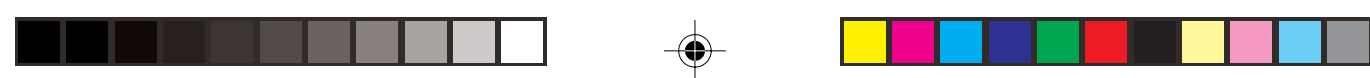

is references to the pronouncements of luminaries such as Robert Reich. Apparently, as one-time secretary of Labor in the first Clinton administration, he is in an 'excellent position' to know that there are no longer any national products or markets. Politicians, of course, have never been known to engage in overblown rhetoric; and Empire, like many other works of meta-theory, consistently confuses the globalisation of ideology and culture (itself exaggerated) with the behaviour of real economic trends and agents.

For example, Alan Rugman (2000) has shown that very few multinational enterprises are global, and that most trade, investment and networks take place within the three main triadic blocks. The service sector, which now employs 70 per cent of the global labour force, is particularly characterised by local or regional activity. ${ }^{6}$

Rugman also notes the success of regional and bilateral trade agreements, compared to global, multilateral initiatives. This would seem to indicate that state power, whether at a national or regional level, is a lot healthier than we would glean from the pages of Empire. The continued existence of protectionist trade wars, subsidies and the use of legal instruments to benefit those inside regional blocs is further proof of this tendency. Hardt and Negri miss this, in part because that is not where they are looking. In place of political economy, we get theorisation of power. Worse, having specified modern governance as existing 'without government', actual states and governance institutions disappear from view.

Yet while the space for states to pursue independent strategies has diminished, it has not been eliminated. States still pursue a repertoire of domestic policies within the broader constraints of global market disciplines (Elger \& Burnham, 2000).

This draws our attention to the continued significance of political struggles within global governance structures. As Callinicos argues, 'Not to recognize the depth of these antagonisms between rival centers of capitalist power is badly to misunderstand the nature of the contemporary world' (200I: 52).

Contrary to Hardt and Negri's ultra-pessimistic view that a politics of civil society is dead, and NGOs absorbed within Empire, such bodies have been instrumental in challenging and re-shaping public policy, as complaints from free-traders such as Rugman testify. 


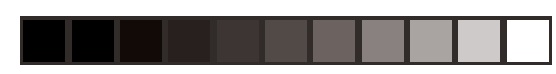

80

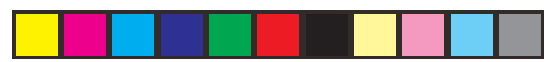

Capital $\mathcal{E}$ Class \#86

Into the hidden abode of production: Immaterial labour and the knowledge economy

There is a part of the discussion of changes in the forms of sovereignty and biopolitical production in which Hardt and Negri foreshadow their later Marxist turn. At the point where post-structuralism reaches its limits, they direct us towards 'a group of contemporary Marxist authors who recognize the biopolitical dimension in terms of the new nature of productive labour and its living development in society, using terms such as "mass intellectuality", "immaterial labour", and the Marxist concept of "general intellect" (pp. 28-9). Though referred to only briefly in the early stages, this body of work is central to the book as a whole.

Despite the Foucauldian line on seamless power and the absorption of resistance, the authors wish to remind us that Empire, and indeed all social formations, are the result of the struggles of labour. Empire argues that the success of the struggles of previous political subjects such as the 'mass worker' compels capital to 'expand inwards' and restructure along two potential pathways: a repressive neo-Fordist technology, and a paradigm shift towards immaterial labour.

We will return to the politics of this version of class struggle later. For the time being, we can note that the authors wish to remind us that since each social formation rests on living labour, we must grasp the importance of production within the biopolitical machine. Immaterial labour (their preferred choice amongst the above terms) is, therefore, at the core of their theoretical framework, and its three primary aspects are elaborated thus: 'the communicative labour of industrial production that has newly become linked in informational networks, the interactive labour of symbolic analysis and problem solving, and the labour of the production and manipulation of effects' (p. 30).

If this language reminds the reader of something prominent in contemporary business and public policy discourses, it is no coincidence. As becomes increasingly clear in the later sections (particularly in 3.4), this appears to be remarkably similar to knowledge economy arguments, which we might briefly summarise in the following way. In the information age, capital and labour are said to have been displaced by the centrality of knowledge; brawn by brain; and the production of goods by services and manipulation of symbols ${ }^{7}$. As a commodity, knowledge is too complex, 

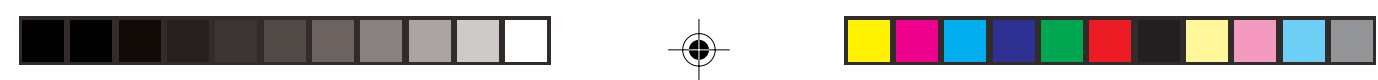

intensive and esoteric to be managed through command and control. The archetypal worker in the new economy makes his or her living from judgement, service and analysis (Leadbetter, 1999). As none of this is calculable or easily measured, it is the inherent property of the producer: 'it remains with the employee and in no real sense is it ever of the firm ... it is impossible to separate knowledge from the knower' (Despres \& Hiltrop, I995: II). This shifts the power balance to the employee, an increasing proportion of whom fall into the category of mobile, self-reliant and demanding 'free workers' (Knell, 2000).

Empire does draw on this literature, but it also supports its assertions through the work of more radical writers, notably Castells. Hardt and Negri borrow his language of 'informationalism', and share the perspective that there is now a mode of informational accumulation (p. 258). Though shaped by capitalist restructuring, it is fundamentally oriented towards the accumulation of knowledge: 'the informational indicates the attribute of a specific form of social organisation in which information generation, gathering, processing and transmission become the fundamental sources of productivity and power' (Castells, 1996: 2I). Castells is not the only radical theorist to go down this route. Lash asserts that what Marx called the labour process is marginalised by a designintensive process, in which 'labour power operates with not practical, but discursive knowledge' (2002: I42).

Hardt and Negri also refer to contemporary developments in economy and work using the label of 'postmodernisation'. Again, what we read is barely different from what can be found in business literature. The line is this: the end of modernisation and the domination of industry has been marked by the growth of service jobs that are highly mobile, flexibly skilled and focused on knowledge, information, affect and communication.

The sphere of production, under the influence of Toyotism ${ }^{8}$, had already shifted towards the centrality of communication and information, but in services the model of communication is richer because the outcome is 'immaterial'-it produces no tangible or durable good. But it is not only services but, increasingly, all forms of work that are weightless and autonomous from any external regime: 'In the passage to postmodernity, one of the primary conditions of labor is that it functions outside measure' (p. 357). The logic of this is taken even further with the argument that cooperation, 


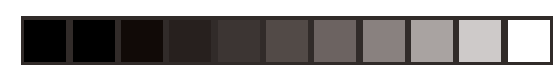

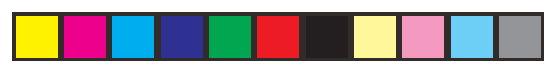

Capital $\mathcal{E}$ Class \#86

rather than being imposed from the outside by capital or its managerial agents, is now 'completely immanent to the labouring activity itself' (p. 294).

Immaterial labour is also said to be analogous to the functioning of the computer; indeed, familiarity with computers and IT is an increasingly central qualification for work. Echoing the ideas of Robert Reich, knowledge-based jobs are based on creative manipulation of symbols and information. The other face of immateriality is its affective character: the labour of human interaction that focuses on feelings and other 'intangibles'. In related writings on immaterial labour, this is linked to the mobilisation of the soul and personality of the worker as an active subject (Lazzarato, undated).

Taken together, information jobs in overlapping manufacturing and service sectors, symbolic analysts and affective labour are said to be the driver of the 'postmodernization of the global economy' (p. 293). In a final act of borrowing from business discourse, it is argued that the assembly line has been replaced by the network as an organisational model.

Horizontally networked enterprises are coordinated through new information technologies that facilitate communication, and break the link between size and efficiency ${ }^{9}$. One can observe a similar line in the recent work of Gorz (I999: 53), who writes 'post-Fordism, the networked interaction of fractal factories and the "immaterial" economy are based on a wealth production which is increasingly disconnected from work and an accumulation of profit increasingly disconnected from any production'.

\section{Critique 2: The materiality of labour}

Even setting aside issues of accuracy, we should not overestimate the originality of much of the material in Empire. The themes of the 'socialised' worker and immaterial labour have been around for a considerable time in Negri's work, but the emergence of a discourse of informational or knowledge economies have given it new context and content. Take, for example, the argument that under conditions of immaterial labour, autonomy has reached its fullest fruitionlabour exists independently of capital, and of 'disciplinary modernisation'. Such arguments were foreshadowed in Hardt 

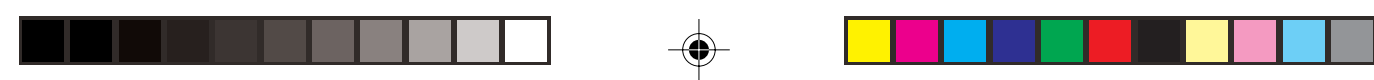

and Negri's (1994) earlier work, in which it was claimed that the cooperation and subjectivity of the technical-scientific 'social workers' exists outside the organisational capacity of capital ${ }^{\mathrm{IO}}$.

The lineage is, however, much longer. Wright (2002: 163) shows that by the mid-I970s, Negri and operaismo had ceased to say much about the mass worker, reaching out instead to a new class subject within which productive intelligence, drawing on intellectual and technical labour, had become determinate. This was not another equivalent of the mass worker, but a means of embracing the whole prole-tariat or anyone in struggle, including students ('pre-workers'), under the concepts of 'socialised worker' and the expanded reproduction of capital.

For all the Marxist language of immaterial labour and self-valorisation, this is fundamentally the same idea as that promoted by management theorists and, as discussed earlier, of the 'free worker' for whom knowledge enables the reversal of power. Or, as another leading organisation theorist put it, 'power in the knowledge economy resides more with workers than owners or managers. Serving the needs of these workers is a leadership imperative' (Bennis, 1999: 37).

In a recent interview, Negri virtually repeats such arguments: 'In the past, labour depended on capital to provide the factory and the tools of production. Today, we have all the tools we need to work in our own heads. This is the end of the distinction between production and life-life and work have become the same thing' (New Statesman, 28 May 200I).

Capital, we are told, is 'always reactive' and is now restructuring to catch up with what has already been created: 'The proletariat actually invents the social and productive forms that capital will be forced to adapt to in the future' ( $p$. 268). While it is important to recognise the influence of labour and its actions on managerial strategy, it is extremely foolish to present events as if capital more or less disappears as actor or agency. Such arguments are theoretically and empirically absurd. Even for the most highly skilled and knowledgeable workers, capitalist forms of ownership and control still provide the context in which commodities are created and exchanged, and thus employment and work organised.

Set aside the radical language found in Empire and much of the critique of knowledge economy arguments is also pertinent. A few points can be highlighted: 


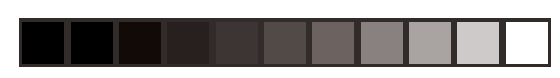

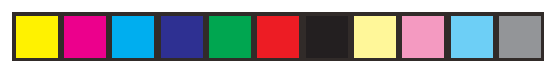

Capital $\mathcal{E}$ Class \#86

- Labour is never immaterial. It is not the content of labour but its commodity form that gives 'weight' to an object or idea in a market economy. Its physicality or otherwise is wholly irrelevant. Knowledge and intangible assets, whether in services or any other form, can be calculated, rationalised, rule-governed and ultimately commodified. One example is the growing significance of patents and new intellectual property regimes in building capital values in 'new economy' companies. At a lower level, employers go to great lengths to define and measure the supposedly intangible character of a service interaction. As one management text puts it, 'Great service should be embedded into a behavioural routine, so it can be properly monitored, measured and managed' (Goodman, 2000: 9).

- The transformation of knowledge or intellect into saleable commodities relies precisely on separating knowledge from the knower. That, after all, is what 'knowledge management' systems are about, as revealed by the language of 'capturing', 'leveraging' or 'converting' knowledge for commercial gain (Neef, 1998: 7). The work of expert or scientific labour is subject to exploitation and control, albeit in different ways to that of routine jobs: for example, through performance metrics, project monitoring procedures, packaged software products and automation. The competitive conditions of large knowledge-based firms compel them to seek ways of significantly reducing the life cycle of 'molecule to market' projects (McKinlay, 2002).

- In some sectors, firms are keen to encourage creativity and to be involved in continuous improvement on the part of workers. However, such changes rely on access to the tacit and informal knowledgeability of labour, rather than on a simple shift from brawn to brain. This can be seen in the increasing reliance of employers on generic or social skills and attitudes, rather than on technical expertise and formal qualifications (Warhurst et al., 2004).

- Knowledge workers with 'thinking skills', who identify and solve problems and manipulate symbols and ideas, 

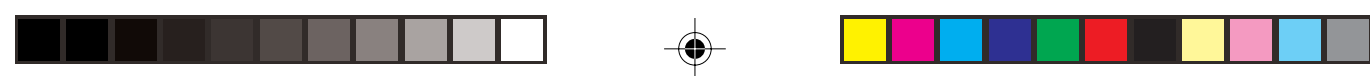

constitute only a small minority of the working population-perhaps Io to I5 per cent in both the Us and the UK (Thompson, Warhurst \& Callaghan, 200I). In an increasingly hourglass economy, in which middlelevel jobs are being squeezed, most actual and forecast job growth has occurred in low-skill, low-wage jobs such as serving, guarding, cleaning, waiting and helping in the private health and care services, as well as in hospitality industries (Nolan, 200I).

- In financialised economies in which capital markets and shareholder value are the dominant drivers of company behaviour (Froud et al., 2002; Thompson, 2003), conditions militate against long-term investment in human capital. Indeed, survey data reveals a process of 'de-knowledging' the firm, as downsizing and redundancy leads to a loss of key skills from the profile of the labour force (Littler \& Innes, 2003; Worrall et al., 2000).

- The idea that the labour process and labour time are no longer significant areas of contestation is belied by a substantial body of research that identifies a rising tide of labour intensification associated with new forms of work organisation and management. The combined effects of work reorganisation and downsizing have led to 'an extraordinary intensification of work pressures' (Burchell et al., I999: 60; and see Green, 200I). One of the sources of intensification is emotional labour, particularly in interactive service work such as in call centres (Callaghan \& Thompson, 2002). Yet Hardt and Negri's discussion of affective work treats it as almost wholly benign, and there is no reference to Hochschild's (1983) or the many more recent critical analyses (e.g. Bolton, 2000) of management use of, and employee resistance to, the mobilisation of feelings.

- There is no evidence that information of itself changes the character of accumulation. In the long term, knowledge and communication intensive industries such as biotechnology (Rifkin, I999) and the internet (Schiller, 1999) do not behave in different ways, nor are they treated differently by markets than more traditional sectors. For example, contrary to the myth 


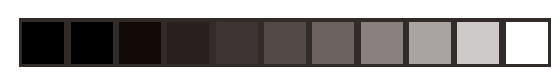

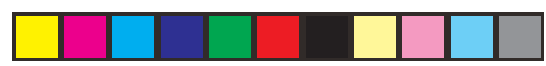

Capital $\mathcal{E}$ Class \#86

of horizontal networks, the concentration of capital (and vertical integration) is unabated.

- While it is true that production has been deterritorialised to an extent, network firms are not a replacement for the assembly line and do not substitute horizontal for vertical forms of coordination. Network firms are a type of extended hierarchy, based, as Harrison observes, on concentration without centralisation: 'production may be decentralised, while power finance, distribution, and control remain concentrated among the big firms' (I994: 20). ${ }^{\text {II }}$ Internal networks do not exist independently of these relations of production; and forms of cooperation, such as teams, are set in motion and monitored by management rather than spontaneously formed.

The most important overall point of critique returns to an earlier theme. For a supposedly Marxist work, there is very little political economy in Empire's analysis of the hidden abode of production. When the 'drivers' of economic and workplace change are discussed, they are located in information or forms of labour, rather than in the dynamics of competition and accumulation. For example, take the question of networks. The discussion in Empire (see pp. 2947) presents them as being driven by the emergence of new means of communication. Yet network production is primarily the outcome of attempts to drive down costs through the externalisation of activities, and of the requirement to address the overall productivity of the whole value-creation chain, largely by reorganising the relations between focal and dependent companies, and by innovation in supply chains and logistics (Altmann \& Deiß, r998).

\section{Counter-empire}

Hardt and Negri are clear that any analysis is deficient that does not give 'a coherent indication of what type of political subjectivities might contest and overthrow the forces of Empire' (p. 205). This point is made at what they describe as a turning-point in their argument-a turning towards counter-Empire. Up to this point, they admit, they have not been able to give such an indication. In one sense, this is 

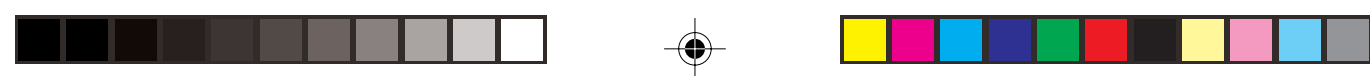

hardly surprising. Given that Empire was constructed largely out of post-structuralist theoretical resources, with all the baggage of totalising power and the all-encompassing nature of the machine, it is not easy to fashion a political subject, let alone one that can challenge the new world order, despite the vague references to resistance.

At this (turning) point, they must delve back into their own version of Marxism. This route is presented unambiguously-'those subjectivities will arrive only on the terrain of production' and 'arise only in practice' (pp. 2056). Fair enough; but the term given to the forces of counterEmpire - 'the multitude' - hardly speaks of class or the hidden abode of production. It is my contention that two political subjects uneasily coexist within Empire; the multitude and the immaterial labourer. To understand this, we have to retrace some of the arguments.

Class struggle and the search for a new political subject

Immaterial labour is part of a long line of theory on the dynamics of class composition and capitalist development. It begins with the struggles of the semi-skilled mass worker for autonomy from work and wage labour, moving to the socialised worker (combining proletarianised intellectual labour and the ranks of the economically and socially marginalised) to form a new political subject and new struggles around the social wage. In earlier work, Negri (I982) draws the conclusion that the terms of exploitation are now relocated on the social terrain, and to life-time rather than labour-time.

This 'methodology', as Hardt and Negri call it, of class composition and struggle places an important emphasis on labour agency as a motor of workplace and social change, and has parallels with the way that LPT views the dialectic of control and resistance (e.g. Edwards, 1979). But it has its downside, particularly in the restless search for new political subjects. During the 1970s, the attention of Negri and his followers turned away from the workplace; 'for the first time in operaismo's history, any necessary relationship between the labour process and class behaviour was to be denied'. (Wright, 2002: 138).

This last is meant more as a comment on the breakdown of close attention to the condition of actual work and workers, than as a comment on political strategy. 


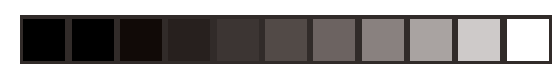

88

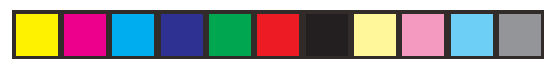

Capital $\mathcal{E}$ Class \#86

Not that the politics was anything but disastrous. Negri felt it not only necessary to move on to new terrains, but to cut links with older political subjects:

Some groups of workers, some sections of the working class, remain tied to the dimension of the wage, to its mystified terms. In other words, they are living off income as revenue. Inasmuch, they are stealing and expropriating proletarian surplus-value - they are participating in the social labour racket-on the same terms as their management. These positions-and the trade union practices that foster them - are to be fought, with violence if necessary. It will not be the first time that a march of the unemployed has entered a large factory so that they can destroy the arrogance of salaried income. (Negri, quoted in Callinicos 200I: 38)

The contemporary political consequences are beyond the scope of this article, ${ }^{12}$ but it is noteworthy that Hardt and Negri continue with the 'methodology' of class composition. In other words, if labour power is always the source of capital, proletarian struggles are the real motor of capitalist development, and these struggles force capital to continually transform the relations of production and domination (p. 208). They repeat the historical analyses of workerism as if history had absolved them and no lessons needed to be learned from the defeats in Italy and beyond. As Callinicos (200I: 54) notes, this historical elision is a convenient means to avoid any reflection on past practices and their limitations. Instead, Hardt and Negri continue to believe that the refusal of work in general, and of factory work in particular, still lies at the heart of the attack on what is now called, with a nod to Foucault, the disciplinary regimes of capitalist labour (p. 26I).

These struggles move seamlessly beyond the factory to demands for a social wage, and to the sphere of non-work and the search for new forms of $\operatorname{life}^{\mathrm{I} 3}$. Thus in an instant, every struggle is joined in a 'virtual unity' and 'objective coincidence' (p. 262). Such a formulation allows Hardt and Negri to link 'decades of proletarian struggle' across every continent, and with any content, on the grounds that they were all directed against the international disciplinary regime of capital. Nor is this an isolated argument. Earlier, they discuss an 'international cycle of struggles' at the end of the century that encompasses Tiananmen Square, the intifada, 

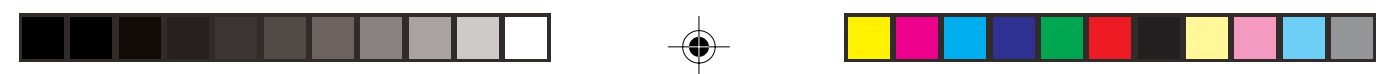

Los Angeles race riots, the Chiapas uprising in Mexico and strikes in France and South Korea. Again, despite or even because of their local specificity, they are all forced to leap vertically to the global level and attack 'the imperial constitution in its generality' (p. 56).

This is reminiscent of Negri's equally facile pronouncements about struggles in Italy in the 1970s, described at the time as 'a pot-pourri of different subjects "with completely autonomous political motivations"' (Wright, 2002: 172). Any disconnection between the theory and actual trends in ideas and actions is covered up by the concept of 'objective recomposition of the class', a category wholly at the mercy of wishful thinking. This self-referential 'methodology' ${ }^{14}$ is therefore immune to the reality or language of defeat. For within the seeds of suppression is always the shape of the next social formation. Capital responds to the new production of subjectivity of the expanded proletariat by instituting a paradigm shift:

The globalization of markets, far from being simply the horrible fruit of capitalist entrepreneurship, was actually the result of the desires and demands of Taylorist, Fordist and disciplined labour power across the world. (p. 256)

There is no mention of anything in the causal chain that might be driven by changes in the nature of competition or capital markets. As observed earlier, capital has disappeared as an actor. So the theoretical and practical dance begins anew.

Under contemporary conditions of political economy, the old working class has disappeared from view, and 'we are faced with the analytical task once again of understanding the new composition of the proletariat as a class' (p. 53), and its desires and needs. The expansion of capitalist production has transformed the proletariat and its struggles, with its fruition in immaterial labour.

The only problem is that it is virtually impossible to find practical expression of the workerist methodology or, put another way, to find actual examples of the concrete desires and struggles of immaterial labourers. This is hardly surprising given the earlier description of the characteristics of this group.

If immaterial labour, possessed of knowledge and the conditions of communication and coordination, already 


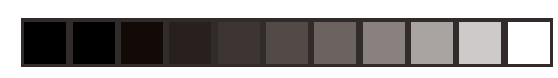

90

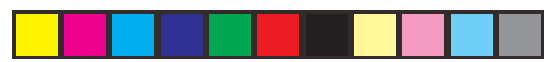

Capital $\mathcal{E}$ Class \#86

embodies the characteristics of capital so that private property is largely anachronistic and Empire parasitical (p. 303), whilst simultaneously providing the potential for a spontaneous and elementary communism (p. 294) - then what would immaterial labourers be struggling for?

Embracing the multitude: In and beyond the workplace

In search of its chosen political subject, Empire must somehow move from immaterial labour to the multitude, from the workplace to the global terrain. As there is no direct route, the move must be achieved by sleight of hand. Sometimes this is purely verbal, as in the reference to a 'multitude of immaterial labourers'. But it is achieved primarily through an argument about the expanded terrain of exploitation and the universal nature of creativity under contemporary living labour power.

For postmodern relations of production are not merely boundaryless, but exist in a non-place: 'These new productive forces have no place, however, because they occupy all places' (p. 2ro). Thus the old argument about the 'socialised worker' is retrieved and renewed. Indeed, towards the end of the book, the term itself is reinstated: it is the figure of the social worker that links immaterial labour to flexible, nomadic life and production (pp. 409-10). Part of this renewal focuses on changes in the conditions of control. This can no longer be achieved in the workplace or through the wage relation, but at the global level through the monetary system, police and communi-cative networks.

Given this situation, the desires of the multitude of mobile and flexible workers can only be pursued outside the workplace, with the focus of struggles shifting from sabotage to desertion (p. 212). In order to escape the disciplinary regime, the 'undisciplined multitude of workers' pursues the variety of openings for mobility. Desire is nomadic in nature, though it must be said that the supporting examples giventhe exodus of highly-trained workers from Eastern Europe, and the movements of IWw agitators, trans-Atlantic Protestant sects and European autonomists from the I970s-are as eclectic as they are unconvincing.

The book ends in a brief concluding section outlining a political programme for what the authors somewhat confusingly refer to as 'postmodern republicanism'. This is not the place for a detailed critique of the politics of Empire (though see Bull, 200I). But what is most notable for our 

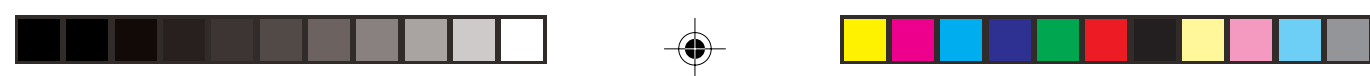

purposes is that Hardt and Negri have managed to construct a political subject from within production, and a politics almost wholly outside it. The third and final leg of that programme is a right to reappropriation-'free access to and control over knowledge, information, communication and affects' (p. 406) - which, though related to previous notions of the autonomy of immaterial labour, is vague and unconvincing. In its romantic obsessions with autonomy, Empire rejects the traditional mechanisms of social change and is suffused with hostility to the welfare state and 'big government'. While they have identified a notional political subject, the picture is incomplete: 'The only event we are still awaiting is the construction ... of a powerful political organization' (p. 4II). Yet there is no mention of unions, the State or parties. Again, this is not new-'biological hatred' of traditional left parties and unions was a fundamental characteristic of early autonomist thinking (Wright, 2002: 6I). Returning to the present, the multitude will apparently organise itself as a 'posse'. As usual, and despite reference to the Renaissance and to us rap groups, no clue is given as to what this might actually look like. This absence is not really surprising, since there will be no mediation between Empire and counter-Empire. Having rejected any actual manifestations of the labour movement, and talked dismissively of NGOS and many social movement bodies, Hardt and Negri can only embrace the multitude in general and anyone who opposes Western hegemony and the passage to (post) modernity. This enables them to embrace Islamic fundamentalists amongst other 'losers' of globalisation.

\section{Conclusion}

Baffled by the 'logic' of one of Empire's central arguments, Wolfe observes: 'Thus one has to read Hardt and Negri's question many times over, so flat out wrong are its assertions and assumptions, in order to judge whether they can possibly be serious' (200I: 2). The task the authors set themselves was serious. But the big picture outlined in Empire, eclectically combining elements of Marxism, managerialism and postmodernism, remains unconvincing and often incomprehensible.

The book is neither a robust guide to the realities and challenges of global governance, nor to the potential for 


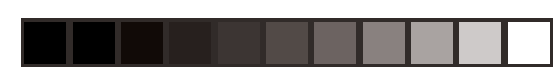

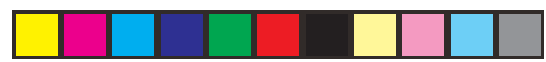

Capital $\mathcal{E}$ Class \#86

social challenge and change. With respect to the latter, Wright argues that the recurrent problem of Negri and operaismo has been a penchant for all-embracing categories, and 'the unrelenting preoccupation with the technical composition of labour power as a key explanation in the explanation of behaviour' (2002: 226). This reached its peak with the socialised worker concept, which flattened differences instead of opening out contradictory dynamics and tendencies. There is much truth in this observation, but the problem runs deeper. Hardt and Negri largely ignore the real insights that can be generated from Marxist political economy, but reproduce what is, arguably, its weakest point-the gravedigger thesis. This search for an economic actor inside the hidden abode of production, who is then required to be a transcendent political subject with the responsibility of changing the whole society, creates an impossible practical and theoretical burden.

Even within these terms, the multitude-'all the subjugated and exploited'-is not a meaningful political subject. Instead of the difficult task of actually mobilising labour, we are presented with a picture of a multitude already formed and victorious. When faced with the reality that potential revolutionaries in various struggles did not recognise either themselves or others as part of an expanding chain of revolt, Hardt and Negri can only take refuge in the banal argument that this was a failure of communication (p. 54-5).

Which leaves us, finally, with their own conclusion. For all the talk of postmodern republicanism, the underlying logic of Empire is an infantile vanguardism. The labour, whether immaterial or multitudinous, in whose name the book speaks is labour to which the communist militant, lauded in the postscript, imputes motives, labels struggles, allocates roles, and proclaims unity of purpose and outcome. Intellectual militants become the means of communication, except that what they are communicating is a fantasy that exists only in their own heads. This is absolutely consistent with the history of Negri and Italian workerism. For all its earlier insights, from its inception this current was distinctive for its view that what labour actually thought was secondary to its position as a particular category of labour (the mass worker, the social worker, immaterial labour, and so on). As Negri remarked of the social worker, 'At the political and social level, this subject presents a complete materialization of consciousness within the structure of its own existence. 

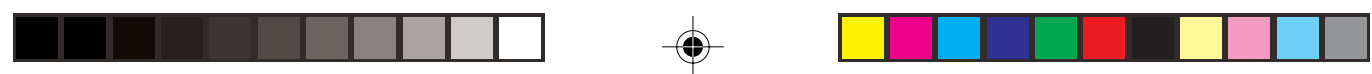

Class consciousness, in other words, comes neither from outside nor from afar: it must be seen as completely internal to, a fact, a thing of class composition' (I982: I4)..$^{\text {IS }}$

In 198I, Negri wrote that the new political generation was more revolutionary because it was without memory (see Wright, 2002: 174-5). Furnished with a partly new language and context, Empire is Negri's (and Hardt's) offering to yet another new generation. This paper has been a contribution to the recovery of memory about a flawed and failed doctrine.

\section{Notes}

* The author would like to thank Valeria Pulignano and Giuliana Commisso for their comments on an earlier version of this paper that was given at the 2002 Labour Process Conference.

I. All page numbers, unless specifically attributed, refer to Empire.

2. Negri was one of the leaders of Autonomia Operaia, the smaller of a number of important far-left parties that came to prominence in the early I970s. The others included Lotta Continua, with whom I was associated. There was some discussion of autonomist ideas in my The Nature of Work (1983, 1989).

For a critical discussion of the broader politics, see Callinicos in International Socialism, Autumn 2001; and for original and contemporary documents from this current, see the Ed Emery archive, online at <http:// www.emery.archive.mcmail.com/index.html>.

3. He goes on to observe that, 'Empire is as much a work of applied poststructuralist philosophy as a piece of concrete historical analysis' (200I: 5I).

4. In this extended analysis, they claim to draw more on Deleuze and Guattari than on Foucault. The former provide a 'properly poststructuralist understanding of biopower that renews materialist thought' (p. 28). Despite the lavish praise, the reference is brief and vague, and within a paragraph the reader is whisked beyond this still 'superficial' and 'ephemeral' analysis to the authors' own school of Italian Marxism.

5. It is common ground in reviews from left to right (Henwood, 200I; Wolfe, 200I; Anderson, 200I) that 


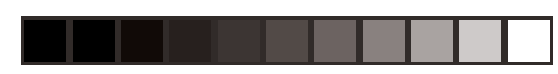

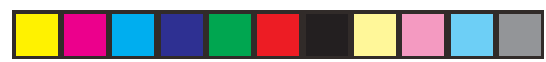

Capital $\mathcal{E}$ Class \#86

assertions and impenetrable waffle frequently replace data and evidence in the book. The forty-five pages of Endnotes are references to further reading from co-thinkers, rather than any attempt to sustain an argument empirically.

6. Only a few sectors, such as consumer electronics, operate on a genuinely global basis, and it is interesting to note that of the multinationals with over two-thirds of their activities outside their home base, most are from smaller, non-triad countries such as Switzerland and Canada (Rugman, 2000: IO-I I).

7. How new all this actually is open to question. Many of the arguments are recycled versions of discredited theories of post-industrialism, resuscitated by managerial writers in search of a language of discontinuity around which to weave their fanciful notions of post-bureaucratic organisation (see Drucker, I986; Handy, I995); or they repeat arguments made by Daniel Bell (1973) about the role of knowledge, made decades earlier.

8. Their account of 'Toyotism' is bizarrely one-sided. All the emphasis is given to new means of communication between production and consumption-presumably a reference to just-in-time systems. No mention is given to the more central role of work organisation and the huge body of radical literature on the negative effects of lean production (e.g. Graham, I995; Rinehart et al., I997; Delbridge, 2000).

9. Hardt and Negri accept that there is some bifurcation of skills and service work across sectors and societies (pp. 286, 292).

Iо. A similar argument is developed by Maurizio Lazzarato (undated): "the cycle of immaterial labour is preconstituted on the basis of a social workforce which is autonomous, and able to organise its own relations with the enterprise. Industry does not form this new workforce, but simply recuperates and adapts it'. As networks and market mobility become the forms of economic coordination, intellectual workers become entrepreneurs and participants in polymorphous intellectual work.

II. To be fair, Hardt and Negri do recognise that networks can involve even more centralised planning and management, or surveillance of workers (p. 297).

I2. While the relationship between Negri, operaismo, the violent street clashes initiated by the autonomists and 

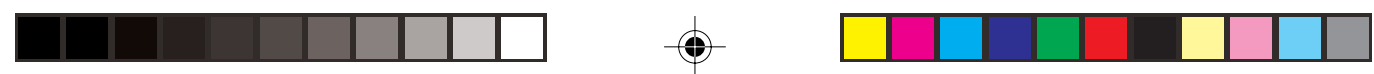

the armed insurrection strategy of the Red Brigades are complex, Wright (2002: I5I) argues that political impatience and a rigid conceptual apparatus led to a misplaced triumphalism and the gamble of militarising the movement.

13. In a particularly foolish passage of radical nostalgia, Hardt and Negri laud counter-cultural struggles, such as US college students taking LSD and dropping out, as the highest form of refusal of any kind of work, and thus of capitalist discipline (p. 274).

I4. Wright quotes Tronti, a fellow Italian workerist theoretician, against Negri: 'A discourse which grows upon itself carries the mortal danger of verifying itself always and only through the successive passages of its own formal logic' (2002: I2).

I5. One aspect of this was a collapse of the distinction between the political and the economic, a perspective reutilised in Empire (e.g. p. 56). Although considerably more sympathetic to these ideas twenty years ago, I wrote then, 'Ultimately, however, the economic is rooted in the use of the concept of class composition itself. Because it is used deterministically it obliterates an analysis of class in a wider sense. The structure of class is presented as class' (Thompson, I98I, emphasis in original).

\section{References}

Altmann, N. \& M. Deiß (I998) 'Productivity by systemic rationalization: Good work, bad work, no work?' in Economic and Industrial Democracy, vol. I9, no. I, pp. I37-I60.

Anderson, B. C. (2002) 'The ineducable Left', in First Things, February.

Bell, D. (1973) The Coming of Post-Industrial Society (Penguin) Harmondsworth.

Bennis, W. (I999) 'The leadership advantage', in F. Hesselbain \& R. Johnston (eds.) On Mission and Leadership (Drucker Foundation).

Bolton, S. (2000) 'Emotions here, emotions there, emotional organisations everywhere', in Critical Perspectives on Accounting, pp. I55-I7I.

Bull, M. (200I) 'You can't build a new society with a Stanley knife: A review of Empire', in London Review of Books, vol. 23, no. I9, 4 October. 


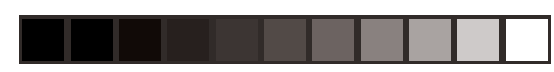

96

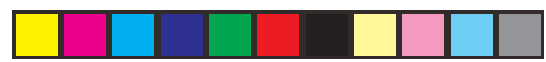

Capital $\mathcal{E}$ Class \#86

Burchell, B. J., D. Day, M. Hudson, D. Ladipo, R. Mankelow, J. P. Nolan, H. Reed, I. C. Wichert \& F. Wilkinson (I999) fob Insecurity and Work Intensification (Joseph Rowntree Foundation) London.

Callaghan, G. \& P. Thompson (2002) "WW Recruit Attitude": The selection and shaping of call centre labour', in fournal of Management Studies, vol. 39, no. 2, pp. 233-254 .

Callinicos, A. (200I) 'Tony Negri in perspective', in International Socialism, Autumn, pp. 33-6I.

Castells, M. (1996) The Rise of the Network Society: The Information Age Economy, Society and Culture, vol. I (Blackwell) Oxford.

Conference of Socialist Economists (1976) The Labour Process and Class Strategies (CSE Books) London.

Crouch, C., D. Finegold \& M. Sako (1999) Are Skills the Answer? The Political Economy of Skill Creation in Advanced Industrial Societies (Oxford University Press).

Delbridge, R. (2000) Life on the Line in Contemporary Manufacturing (Oxford University Press).

Despres, C. \& J. M. Hiltrop (I995) 'Human resource management in the knowledge age: Current practice and perspectives on the future', in Employee Relations, vol. I7, no. I, pp. 9-23.

Drucker, P. (1986) 'The changed world economy', in Foreign Affairs, vol. 64, no. 4, pp. 768-791.

Edwards, R. (1979) Contested Terrain: The Transformation of the Workplace in the Twentieth Century (Heinemann) London.

Elger, T. \& P. Burnham (200I) 'Labour, Globalization and the "Competition State", in Competition and Change, pp. I-23.

Froud, J., S. Johal \& K. Williams (2002) 'Financialisation and the coupon pool', in Capital $\mathcal{E}$ Class, no. 78, pp. II9-I5I.

Gorz, A. (1999) Reclaiming Work: Beyond the Wage-Based Society (Polity Press) Cambridge.

Graham, L. (1995) On the Line at Subaru-Isuzu: The Fapanese Model and the American Worker (ILR Press) Ithaca, NY.

Green, F. (200I) 'It's been a hard day's night: The concentration and intensification of work in late twentieth century Britain', in British Fournal of Industrial Relations, vol. 39I, no. I, pp. 53-80.

Handy, C. (1995) The Future of Work, WH Smith Contemporary Papers, no. 8.

Hardt, M. (200I) 'An article on Toni Negri and his intention to return to prison in Italy', available online at Ed Emery's Toni Negri archive, at <http://www.emery.archive.mcmail.com/ public_html/toni_negri/hardt.html $>$.

Hardt, M. \& A. Negri (I994) Labor of Dionysus: A Critique of the State-Form (University of Minnesota Press) Minneapolis.

Hardt, M. \& A. Negri (2000) Empire (Harvard University Press). 

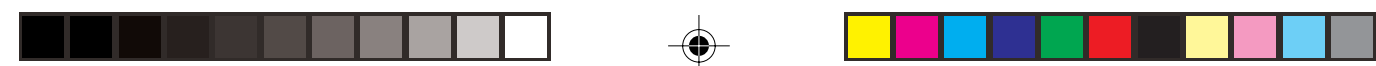

Harrison, B. (1994) Lean and Mean: The Changing Landscape of Corporate Power in the Age of Flexibility (Basic Books) New York.

Henwood, D. (200I) 'Blows against Empire', in Left Business Observer, no. 96, February.

Hochschild, A. R. (1983) The Managed Heart: Commercialisation of Human Feeling (University of California Press) Berkeley \& Los Angeles.

Knell, J. (2000) Most Wanted: The Quiet Birth of the Free Worker (The Industrial Society) London.

Lash, S. (2002) Critique of Information (Sage) London.

Lazzarato, N. (undated) 'General intellect: Towards an inquiry into immaterial labour', available online at Ed Emery's Toni Negri archive, at <http://www.emery.archive.mcmail.com/ public_html/immaterial/lazzarat.html $>$.

Leadbetter, C. (1999) Living on Thin Air: The New Economy (Viking) London.

Littler, C. R. \& P. Innes (2003) 'Downsizing and deknowledging the firm', in Work, Employment and Society, vol. I7, no. I, pp. 73-100.

McKinlay, A. (2002) 'The limits of knowledge management', in New Technology, Work and Employment, vol. I7, no. 2, pp. 76-88.

Neef, D. (ed.) (1998) The Knowledge Economy (Butterworth Heinemann) New York.

Negri, A. (I982) 'Archaeology and project: The mass worker and the social worker', online at Class Against Class, at http://www.geocities.com/cordobakaf/massworker.html.

Omhae, K. (1990) The Borderless World (Collins) London.

Rifkin, J. (1999) The Biotech Century (Tarcher Putnam) New York.

Rinehart, J., C. Huxley \& D. Robertson (1997) Fust Another Car Factory? Lean Production and its Discontents (Cornell University Press) Ithaca, NY.

Rugman, A. (2000) The End of Globalization (Random House Books) London.

Schiller, D. (I999) Digital Capitalism (MIT Press) Boston.

Thompson, P. (I98I) 'Theories of the labour process', unpublished Ph.D. thesis, Liverpool University.

Thompson, P., C. Warhurst \& G. Callaghan (2000) 'Ignorant theory and knowledgeable workers: Interrogating the connections between knowledge, skills and services', in fournal of Management Studies, vol. 38, no. 7, pp. 923-942.

Warhurst. C., I. Grugulis \& E. Keep (eds.) The Skills That Matter (Palgrave) London.

Wolfe, A. (200I) 'The snake: A review of Empire', in The New Republic, Io January. 


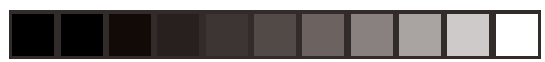

98

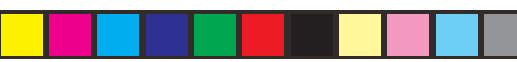

Capital $\mathcal{E}$ Class \#86

Worrall, L., C. Cooper \& F. Campbell (2000) 'The new reality for UK managers: Perpetual change and employment instability', in Work, Employment and Society, vol. I4, no. 4, pp. 647-668.

Wright, S. (2002) Storming Heaven: Class Composition and Struggle in Italian Autonomist Marxism (Pluto Press).

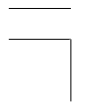

